\title{
$\mathrm{Ca}-10 *$
}

可溶性スターチシンターゼ活性を極限まで抑えた二重変異体米の澱粉構造および生理生化学的特性解析 秋田県立大・生物資源

○林真里，児玉桃子，中村保典，藤田直子

【目的】澱粉の直鎖を伸長するスターチシンターゼ（SS）はイネにおいて 11 個のアイソザイム遺伝子が存在する。中で も SSI と SSIIIa は登熟胚乳の可溶性画分のそれぞれ約 6 割と約 3 割の SS 活性を有するアミロペクチン合成の主要 な酵素である。SSI と SSIIIa を同時に完全欠損させると不稔になるが、SSI 活性が 1/6 に低下したリーキ一変異体 $s s 1^{L}$ を片親とすることで、 $s s 1^{L} / s s 3 a$ 二重変異体固定系統が作出された (Fujita et al., 2011，J. Exp. Bot.)。本研究 では、可溶性 SS 活性を極限まで抑えた ss1 / ss3a の澱粉構造および生理生化学的特性を解析した。

【方法】二重変異体 $s s 1^{1} / s s 3 a$ 、両親系統 $s s 1^{L}$ および $s s 3 a$ 、野生型として日本晴それぞれの登熟種子、完熟種子および 精製澱粉を実験に供した。各系統の種子形態、澱粉含量および AGPase 活性の測定を行った。キャピラリ一電気泳動法お よびゲル濾過法によりアミロペクチンの鎖長パターンを明らかにした。またSS 欠損による他の澱粉生合成関連酵素への 影響を明らかにするために、Native-PAGE 活性染色による酵素活性検出と澱粉粒結合性タンパク質の検出を試みた。

【結果】 $s s 1^{1} / s s 3 a$ の種子重量と澱粉含量はそれぞれ日本晴と比較して $89 \%$ と $64 \%$ であり、ss3a と同様の傾向を示した。 $s s$ l $/$ ss3a の AGPase 活性は日本晴の 1.8 倍となり、過剰な基質供給によりアミロース合成が促進されたことが示唆され た。SS 欠損による他の可溶性酵素活性への影響は見られなかったが、SSIIa，BEI，BEII の澱粉粒結合特性が変化した。

\section{Ca-11* 低カロリ一効果が期待できる高難消化性澱粉変異体米の老化性と澱粉構造}

秋田県立大・生物資源

○立木芳, 藤田直子

【目的】肥満、糖尿病、大腸癌予防に有効である難消化性澱粉 (RS) を多く含む変異体米から低カロリ一米食品の開発を目 指している。昨年度、高アミロース米を中心とした変異体米から、特に RS を多く含むのは、澱粉枝作り酵素 (BE) IIb が欠 損している変異体系統であることを明らかにした。残念ながら、これらの系統の炊飯米は非常にパサパサしており、食味 がすぐれない。本研究では、これらの原因を解明し、RS の分子構造を予想することを目的とした。

【方法】炊飯米の老化性を調べるため、炊飯直後から、さまざまな時間冷蔵保存した炊飯米にエタノールを加えて、老化 を停止させ、乾燥させた後に粉砕した。湿度 $100 \% 、 24$ 時間放置したものの結晶性をX 線回折装置で調べた。炊飯米をメガ ザイムの RS 測定キットに付属の $\alpha$-アミラーゼおよびアミログルコシダーゼで処理して可溶化した成分を除去し、残存した RS をジメチルスルフォキシドで煮沸して可溶化した。イソアミラーゼで枝切り処理し、ゲル濾過カラムで分離した。

【結果】高 RS 值を示す $s s 3 a / b e 2 b$ 系統は、炊飯後わずか 5 分後にX 線回折による結晶性が検出された。このことから、 $s s 3 a / b e 2 b$ 炊飯米は、老化が著しく速く、それが食味がすぐれない原因であることが示唆された。また、BEIIb 欠損変異 体の RS のゲル濾過による分子量分布は、元の港粉のパターンとは全く異なり、アミロースとアミロペクチンの長鎖が未分 解のまま残存したと考えられる分子量に多くが検出された。これらの系統の RS 構造モデルについて議論する。

\section{Cp-1 サケ軟骨の水脱脂粉末に含まれるプロテオグリカンとヒアルロン酸の分析}

弘前大 - 院医 - 高度先進医学研究セ ${ }^{1}$, 弘前大 - 教育 ${ }^{2}$, 静岡県大院 ·食品栄養科学 ${ }^{3}$, 山形大院 $\cdot$ 理工 $^{4}$ O柿崎育子 ${ }^{1}$, 三浦絢子 ${ }^{2}$, 伊藤聖子 ${ }^{3}$, 峯田貴 ${ }^{4}$, 洪振瑞 ${ }^{4}$, 加藤陽治 ${ }^{2}$

【目的】軟骨型プロテオグリカン (PG) を含有する食品素材の原料であるサケ頭部は、PG 調製時まで冷凍保存されている が、保存スペースをとるだけでなく、冷凍中の劣化も眯念される。これまでに、冷凍サケ頭部の軟骨を新鮮なうちに処理 し粉末として保存する方法、水脱脂粉末化法が確立され、得られた粉末の安全性や機能性が調べられてきた。本研究では、 この粉末に含まれるプロテオグリカンおよびヒアルロン酸 (HA) の品質を明らかにするため、構造に関する分析を行った。 【方法】サケ軟骨の水脱脂粉末の 4M グアニジン塩酸抽出物から、DEAE-Sephacel 陰イオン交換クロマトグラフィーにより、 コンドロイチン硫酸-PG (ChS-PG) とHA を分離した。ChS-PG 含有画分について、Sepharose CL-4B ゲルろ過クロマトグラ フィーにより PG をさらに精製した。精製 PG の不飽和二糖分析、HPLCによるサイズ分析、原子間力顕微鏡による全体像の 観察、ドットブロットによるコアタンパク質のドメイン構造の分析を行った。HAについてはサイズ分析を行った。

【結果】水脱脂粉末中に含まれるPG のコアタンパク質、グリコサミノグリカン糖鎖を含む全体構造は、天然型のサケ軟骨 PG の構造を保持していた。この粉末に含まれるヒアルロン酸もサケ軟骨の天然型のヒアルロン酸と同様に高分子量であっ た。従って、水脱脂粉末化法によってサケ頭部の保存の問題点が改善されるだけでなく、水脱脂粉末からの第 2 ステップ として抽出、精製を行えば、高分子のPG と HA が効率的に得られることが示された。

\section{$\mathrm{Cp}-2$}

サケ軟骨の水脱脂粉末中のプロテオグリカンに与える加熱処理の影響

弘前大・教育 ${ }^{1}$, 弘前大 · 院医・高度先進医学研究セ ${ }^{2}$

○三浦絢子 ${ }^{1}$, 藤田典子 ${ }^{1}$, 杮崎育子 ${ }^{2}$, 加藤陽治

【目的】プロテオグリカン $(\mathrm{PG})$ の新たな供給源として、サケ軟骨の水脱脂粉末の利用が期待されている。これまでに粉末からの $P G$ 抽出方法を検討した結果、水抽出物中にも天然型とみられる高分子量 PGの存在が示唆されたものの、収率の低さが課題とな っていた。本研究では水抽出における PG 抽出効率の向上を念頭に、加熱処理が収量や構造に与える影響について知見を得るこ とを目的とした。

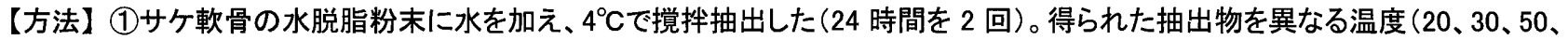

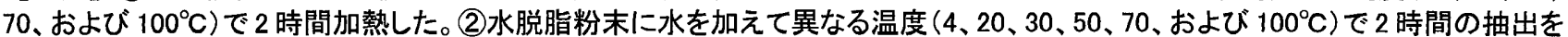
行った。各試料について Sepharose CL-4B ゲルろ過クロマトグラフィーを行い、得られたPGの分子量分布を比較した。抽出物中の PG は DEAE Sephacel 陰イオンクロマトグラフィーで精製し、コアタンパク質のドメイン構造をドットブロット法により分析した。

【結果】(1)加熱処理による分子量分布の変化は認められず、熱安定性が確認された。(2)水を溶媒とした加熱抽出では、得ら

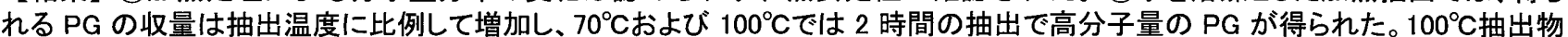
においてはコアタンパク質の G1 および G3ドメインの両方が認められたことから、サケ軟骨の水脱脂粉末に対する熱水抽出は、天 然型のサケ軟骨 PG を簡便に抽出する方法として有用であることが示唆された。 